\title{
AKTIVITAS ANTIBAKTERI BIJI JERUK MANIS (Citrus sinensis) TERHADAP BAKTERI Escherichia coli
}

\author{
Mohammad Arfi Setiawan $^{1^{*}}$, Mita Dewi Retnoningrum² \\ ${ }^{1}$ Fakultas Teknik Kimia, Fakultas Teknik, \\ Universitas PGRI Madiun \\ Jl. Auri no 14-16 Madiun, Jawa Timur, Indonesia \\ ${ }^{2}$ Fakultas Matematika dan Ilmu Pengetahuan Alam Program Studi Biologi, Universitas Billfath \\ Siman, Sekaran, Lamongan, Jawa Timur, Indonesia \\ *Email: marfis@yahoo.com
}

\begin{abstract}
Abstrak
Perkembangan penyakit pada manusia saat ini semakin beragam dan berjalan relatif cepat. Salah satu penyebab timbulnya berbagai penyakit tersebut yaitu mikroorganisme seperti bakteri Escherichia coli. Pengobatan yang biasa dilakukan masyarakat yaitu menggunakan obat-obatan kimia, yang dapat menimbulkan efek resisten pada bakteri bahkan efek samping bagi pasien, sehingga penting untuk dilakukan usaha pemanfaatan tanaman sebagai bahan obat herbal dengan memanfaatkan limbah biji buah jeruk manis sebagai antibakteri. Penelitian ini bertujuan untuk mengetahui aktivitas antibakteri biji jeruk (Citrus sinensis) terhadap bakteri Escherichia coli. Jenis penelitian ini adalah eksperimental laboratorium dengan menggunakan metode difusi untuk uji aktivitas antibakterinya. Penelitian dilakukan dengan tahapan sebagai berikut: (1) preparasi sampel berupa serbuk biji jeruk, (2) maserasi serbuk biji jeruk dengan pelarut n-heksana dan etanol, (3) uji antibakteri. Hasil penelitian menunjukkan bahwa biji jeruk menghambat pertumbuhan bakteri E.coli dengan zona hambat ekstrak n-heksan dan etanol sebesar 7,93 $\pm 1,90 \mathrm{~mm}$ dan 18,27 $\pm 2,40 \mathrm{~mm}$. Biji jeruk manis (Citrus sinensis) memiliki potensi sebagai antibakteri.
\end{abstract}

Kata Kunci: antibakteri, Citrus sinensis, ekstraksi biji jeruk, Escherichia coli

\begin{abstract}
Development of disease in humans is increasingly diverse and runs quickly. One cause of the incidence of various diseases are microorganisms such as Escherichia coli. The usual treatment is the use of chemical drugs, which can cause the effects of resistance to bacteria and even side effects for patients, so it is important to do business utilization of plants as herbal medicinal materials by utilizing the waste of sweet orange seeds as an antibacterial. This study aims to determine the antibacterial activity of orange seeds (Citrus sinensis) against Escherichia coli. This study is designed as an laboratory experimental with diffusion method for the antibactey test. The study was conducted with the following stages: (1) preparation of the sample of orange seed powder, (2) maseration of orange seeds powder with n-hexane and ethanol solvent, (3) antibacterial test. The results showed that orange seeds inhibited the growth of Escherichia coli with inhibition zone of n-hexane and ethanol extracts of $7.93 \pm 1.90 \mathrm{~mm}$ and $18.27 \pm 2.40 \mathrm{~mm}$. Sweet orange seeds (Citrus sinensis) have the potential as antibacterial.
\end{abstract}

Keywords: antibacterial, Citrus sinensis, Escherichia coli, orange seeds extract

\section{Pendahuluan}

Buah jeruk manis (Citrus sinensis) merupakan salah satu buah yang banyak digemari oleh masyarakat. Selain karena rasanya manis, buah ini bisa dimanfaatkan sebagai obat herbal penyakit infeksi yang disebabkan oleh mikroorganisme. Salah satunya yaitu bakteri Escherichia coli, meskipun beberapa jenis tidak membahayakan, namun akan dapat merugikan kesehatan apabila tidak ditangani dengan baik. Pengobatan yang biasa dilakukan yaitu dengan menggunakan obat-obatan kimia, namun pengobatan kimia tersebut dapat menimbulkan efek samping apabila dosisnya kurang tepat. Solusi yang dapat dilakukan yaitu dengan memanfaatkan bahan alam dari tanaman, salah satunya dengan melakukan pemanfaatan limbah buah jeruk manis berupa bijinya yang diduga berpotensi sebagai antibakteri. Penelitian tanaman jeruk sebagai antibakteri sudah banyak dilakukan khususnya pada bagian kulit jeruk. Ekstrak heksana kulit buah 12 varietas Citrus sinensis menghambat bakteri Staphylococcus aureus, 
Listeria monocytogens dan Pseudomonas aeruginosa (Geraci et al, 2016). (Geraci, Stefano, Martino, Schillaci, \& Schicchi, 2016).

Uji aktivitas antibakteri kulit buah $C$. sinensis dengan pengekstrak etanol, metanol, aseton, kloroform dan eter (Shetty, et al., 2015). Hasil menunjukkan bahwa semua ekstrak relatif menghambat bakteri Escherichia coli, Klebsiella pneumoniae, Pseudomonas aeruginosa, Salmonella typhi, Salmonella paratyphi A, Salmonella paratyphi $B$, Shigella flexneri dan Vibrio cholerae. Perbandingan aktivitas antibakteri dari kulit buah C. sinensis dan $C$. aurantium terhadap bakteri Klebsiella pneumoniae dan Bacillus cereus (Madhuri, Ashwini, Srilakhsmi, \& Kekuda, 2014). Kulit buah C. sinensis memiliki aktivitas antibakteri lebih tinggi daripada kulit buah C. aurantium. Aktivitas antibakteri kulit buah $C$. sinensis terhadap Staphylococcus aureus, Salmonella dan Clostridium sulfite reducers (Yerou, Bouhadi, Meddah, \& Touil, 2017). Uji aktivitas antibakteri kulit buah jeruk nipis Citrus aurantifolia juga telah banyak dilaporkan. Ekstrak kulit buah jeruk nipis dengan konsentrasi 10\% menghambat aktivitas enzim glukosiltransferase Streptococcus mutans penyebab karies gigi (Adindaputri, Purwanti, \& Wahyudi, 2013). Perasan jeruk nipis juga memiliki aktivitas antibakteri terhadap Escherichia coli (Berlian, Fatiqin, \& Agustina, 2016). Selain sebagai antibakteri, kulit buah jeruk juga dapat berfungsi sebagai antioksidan (Yerou, Bouhadi, Meddah, \& Touil, 2017) dan antijamur (Madhuri, Ashwini, Srilakhsmi, \& Kekuda, 2014). Berdasarkan penelitian Madhuri et al., (2014) kulit buah jeruk Citrus sinensis dan Citrus aurantium menghambat pertumbuhan jamur Colloetotrichum capsici.

Seperti halnya kulit buah jeruk yang memiliki banyak manfaat, biji jeruk juga memiliki beragam manfaat. Biji jeruk yang biasanya dibuang dan merupakan sampah ternyata memiliki kandungan asam lemak omega yang bermanfaat untuk mengurangi peradangan, asam salisilat yang kegunaannya sama seperti aspirin untuk meringankan rasa sakit dan nyeri. Selain itu, terdapat limonin yang merupakan senyawa limonoid yang dapat menghambat pertumbuhan tumor (Okwu, 2008).

Manfaat lain dari biji jeruk yaitu sebagai antioksidan alami adalah minyak biji jeruk manis
(Citrus sinensis) mengandung karotenoid, senyawa fenolik, $\alpha$-tokoferol, dan fitosterol (Jorge, Silva, \& Aranha, 2016). Pemanfaatan biji jeruk sebagai antibakteri belum banyak dilakukan selama ini, sehingga dilakukan penelitian aktivitas antibakteri biji jeruk manis (Citrus sinensis) terhadap Escherichia coli. Penelitian ini bertujuan untuk mengetahui aktivitas antibakteri biji jeruk manis, sehingga hasil dari penelitian ini diharapkan menjadi alternatif bahan alami yang dapat digunakan sebagai antibakteri.

\section{Material Dan Metode}

Penelitian ini mulai dilakukan pada bulan Februari 2018. Pemisahan ekstrak dengan pelarut dilakukan di Laboratorium SMK 3 Madiun, sedangkan untuk uji aktivitas antibakteri, dilakukan di laboratorium Biologi Unversitas Negeri Malang.

Alat yang digunakan dalam penelitian adalah seperangkat alat destilasi. Bahan yang digunakan dalam penelitian adalah biji jeruk manis (Citrus sinensis) yang dikumpulkan dari penjual, n-heksana, etanol, Escherichia coli, aquades steril, media Salmonella Shigella Agar (SSA), Nutrient Agar (NA), dan chloramphenicol.

\section{Pelaksanaan penelitian}

a. Preparasi Sampel

Biji jeruk manis yang sudah dikumpulkan selanjutnya dikeringkan. Biji yang telah kering digiling sampai menjadi serbuk. Bentuk serbuk akan memperluas bidang sentuh sampel sehingga proses ekstraksi menjadi lebih optimal (Gambar 1).

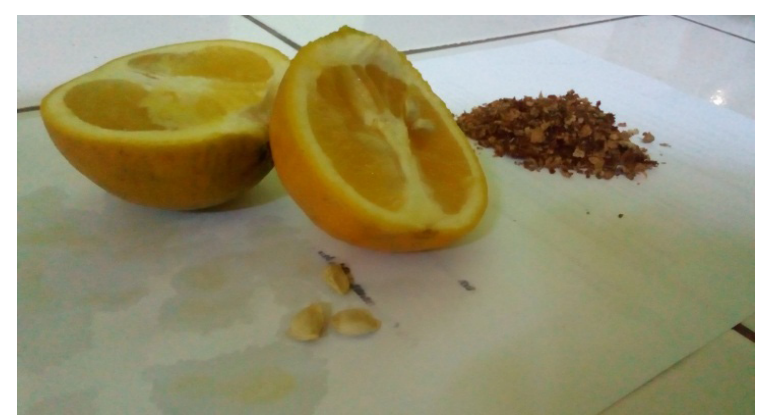

Gambar 1. Biji Jeruk Manis dan Serbuk Biji Jeruk Manis 
b. Ekstraksi Sampel

Serbuk biji jeruk manis (Citrus sinensis) dimasukkan ke dalam wadah maserator. Selanjutnya ditambahkan n-heksana dan didiamkan selama 24 jam. Setelah 24 jam dilakukan penyaringan sehingga diperoleh residu dan filtrat. Residu dilanjutkan maserasi dengan etanol, sedangkan filtrat hasil penyaringan dievaporasi untuk menghilangkan pelarut dan hasilnya diberi nama FH (Filtrat n-Heksan). Residu dimasukkan ke wadah maserator, ditambahkan etanol dan didiamkan selama 24 jam. Setelah 24 jam dilakukan penyaringan sehingga diperoleh residu dan filtrat. filtrat hasil penyaringan dievaporasi untuk menghilangkan pelarut dan hasilnya diberi nama FE (Filtrat Etanol).

c. Uji Aktivitas Antibakteri

Uji aktivitas antibakteri ekstrak n-heksana dan etanol biji jeruk manis dilakukan dengan mensterilisasi semua peralatan yang akan digunakan. Pengujian antibakteri dilakukan dengan menyiapkan semua alat dan bahan dalam laminar air flow. Starter bakteri $E$. coli selanjutnya dimasukkan ke dalam media agar yang siap pakai sebanyak $10 \mu \mathrm{L}$ dan diratakan secara searah. Kertas cakram yang sudah mengandung sampel kemudian dimasukkan ke dalam media agar yang berisi bakteri. Medium yang telah diisi dengan sampel dan bakteri dimasukkan ke dalam inkubator kemudian diinkubasi pada suhu $37^{\circ} \mathrm{C}$ selama 24 jam. Untuk memvalidkan data, dilakukan pengulangan sebanyak tiga kali. Pada uji aktivitas antibakteri digunakan kontrol + berupa Chloramphenicol dan kontrol - berupa akuades. Kontrol diperlukan sebagai pembanding zat yang dilakukan uji aktivitas antibakteri.

d. Analisis Data

Uji aktivitas antibakteri dilakukan dengan mengukur zona hambat. Data dianalisis dengan ANOVA satu jalur. Jika data signifikaan dilanjutkan dengan uji DMRT.

\section{Hasil dan Pembahasan}

Filtrat hasil maserasi memiliki perbedaan warna, yaitu $\mathrm{FH}$ memiliki warna lebih terang daripada FE yang dapat dilihat pada Gambar 2. Hal ini mengindikasikan kandungan senyawa dalam kedua fitrat tersebut berbeda.

Setelah dilakukan pengujian aktivitas antibakteri, diketahui bahwa FH dan FE memiliki daya hambat terhadap bakteri Escherichia coli. $\mathrm{Hal}$ tersebut diketahui dari terdapatnya zona hambat dari tiap pengulangan. Zona hambat menandakan tidak adanya bakteri yang tumbuh (Gambar 3).

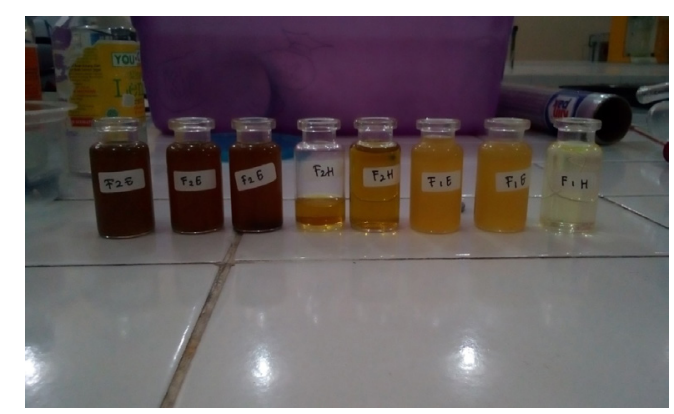

Gambar 2. Hasil Ekstraksi Biji Jeruk dengan n-Heksana (FH) dan Hasil Ekstraksi Biji Jeruk dengan Etanol (FE)

Pengukuran diameter zona hambat tersebut diperoleh rata-rata sebesar 7,93 $\pm 1,90 \mathrm{~mm}$ untuk

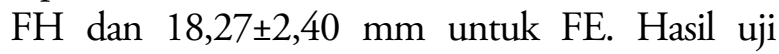
ANOVA satu jalur diketahui bahwa data signifikan dengan $0,002<0,05$. Secara lebih detail data dapat dilihat pada Tabel 1 . Hasil tersebut menunjukkan adanya perbedaan rata-rata daya hambat bakteri, sehingga dilakukan uji lanjutan DMRT. Hasil uji DMRT diketahui bahwa rata-rata daya hambat tidak berbeda secara signifikan terhadap kontrol (akuades). Namun, aktivitas antibakteri biji jeruk manis terhadap bakteri Escherichia coli diketahui bahwa FE (ekstrak etanol) memiliki daya hambat yang lebih tinggi daripada $\mathrm{FH}$ (ekstrak n-heksana).

Warna filtrat dan hasil uji antibakteri yang berbeda antara FH (ekstrak n-heksana) dan FE (ekstrak etanol) menandakan bahwa kandungan dalam ekstrak yang berbeda. Ekstrak etanol biji jeruk manis (Citrus sinensis) mengandung 
alkaloid, flavonoid dan steroid (Oikeh, Oriakhi, \& Omoregie, 2013).

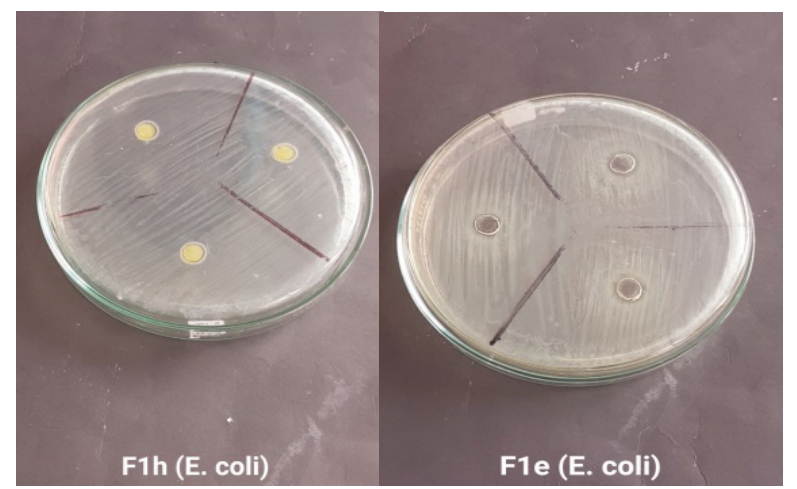

Gambar 3. Uji Aktivitas Antibakteri Ekstrak Biji Jeruk dengan n-Heksana (FH) dan Ekstrak Biji Jeruk dengan Etanol (FE)

Warna filtrat dan hasil uji antibakteri yang berbeda antara FH (ekstrak n-heksana) dan FE (ekstrak etanol) menandakan bahwa kandungan dalam ekstrak yang berbeda. Ekstrak etanol biji jeruk manis (Citrus sinensis) mengandung alkaloid, flavonoid dan steroid (Oikeh, Oriakhi, \& Omoregie, 2013). Kandungan ekstrak etanol biji jeruk manis (Citrus sinensis) antara lain tanin, steroid, flavonoid dan terpenoid (Oke \& Akeju, 2017). Sedangkan ekstrak n-heksana mengandung minyak dengan komposisi asam lemak yaitu, asam palmitat, asam stearat, asam arakhidat, asam trikosilat, asam heneikosilat, asam palmitoleat, asam oleat, dan asam linoleat (Oluremi, Akinkunmi, Ajayi, Kilanko, \& Adefemi, 2016).

Biji jeruk manis (Citrus sinensis) mengandung flavonoid dan minyak. Hal ini menandakan biji jeruk manis memiliki banyak kegunaan seperti antibakteri dan sebagai bahan sintesis biodiesel. Pembuatan biodiesel dari biji jeruk manis dengan efisiensi 96,82\% menggunakan reaksi transesterifikasi (Azad, 2017).

\section{Simpulan}

Biji jeruk manis (Citrus sinensis) memiliki potensi sebagai antibakteri. Hasil penelitian menunjukkan bahwa ekstrak n-heksana (FH) dan ekstrak etanol (FE) menghambat pertumbuhan bakteri Escherichia coli dengan diameter zona hambat berturut-turut 7,93 $\pm 1,90 \mathrm{~mm}$ dan $18,27 \pm 2,40 \mathrm{~mm}$.

\section{Ucapan Terimakasih}

Kami mengucapkan terimakasih kepada Universitas PGRI Madiun yang telah membantu pendanaan agar penelitian ini terlaksana.

\section{DAFTAR PUSTAKA}

Adindaputri, U. Z., Purwanti, N., \& Wahyudi, I. A. (2013). Pengaruh Ekstrak Kulit Jeruk Nipis (Citrus aurantifolia Swingle) Konsentrasi 10 \% Terhadap Aktivitas Enzim Glukosiltransferase Streptococcus mutans. Majalah Kedokteran Gigi., Vol 20(2):126-131.

Azad, A. (2017). Biodiesel from Mandarin Seed Oil: A Surprising Source of Alternative Fuel. Energies, Vol $10: 1-22$.

Berlian, Z., Fatiqin, A., \& Agustina, E. (2016). Penggunaan perasan Jeruk nipis (Citrus aurantifolia) dalam Menghambat Bakteri Escherichia coli pada Bahan Pangan .Jurnal Bioilmi, Vol. 2 No. 1 hal 51-.

Geraci, A., Stefano, V. D., Martino, E. D., Schillaci, D., \& Schicchi, R. (2016). Essential oil components of orange peels and antimicrobial activity. Natural Product research, 1-8.

Jorge, N., Silva, A. C., \& Aranha, C. P. (2016). Antioxidant activity of oils extracted from orange (Citrus sinensis) seeds. Annals of the Brazilian Academy of Sciences, Vol 88(2): 951-958.

Madhuri, S., Ashwini, U., Srilakhsmi, N., \& Kekuda, T. P. (2014). Antimicrobial activity of Citrus sinensis and Citrus aurantifolium Peel Extracts. Journal Pharmacheutical and Scientific Innovation, Vol 3 (4) : 366-368.

Oikeh, E., Oriakhi, K., \& Omoregie, E. (2013). Proximate Analysis and Phytochemical Screening of Citrus sinensis Fruit Wastes . The Bioscientist, Vol. 1(2):164-170. 
Oke, I. S., \& Akeju, A. (2017). Laboratory evaluation of extract from peels and seeds of some Citrus species against Anopheles mosquitoes (Diptera: Culicidae) . International Journal of Mosquito Research, Vol 4(5): 48-54.

Okwu, D. E. (2008). Citrus Fruits : A Rich Sources of Phytochemicals and Their Roles and Human Health. Int. Journal Chem. Science, Vol 6(2) : 451-471.

Oluremi, O. I., Akinkunmi, E. O., Ajayi, O. S., Kilanko, O., \& Adefemi, G. (2016). Physicochemical and in vitro antimicrobial activity of the oils and soap of the seed and peel of Citrus sinensis . African Journal of Microbiology Research, Vol 10 (8) : 245 - 253.

Shetty, S. B., Ismail, P. M.-S., Varghese, S., Thomas-George, B., Kandathil-Thajuraj, P., Baby, D., ... Devang-Divakar, D. (2015). Antimicrobial effects of Citrus sinensis peel extracts against dental caries bacteria: An in vitro study. Journal section: Community and Preventive Dentistry, e71-e78.

Yerou, K. O., Bouhadi, K. I., Meddah, B., \& Touil, A. T. (2017). The Use of Orange (Citrus sinensis) Peel as Antimicrobial and Antioxidant Agent. Journal of Fundamental and Applied Sciences, Vol 9(3), 1351-1357. 